\title{
Against Orthodoxy: Sex, Marriage, and Gender Roles in George Meredith’s Poems and Novels
}

\author{
Anna Enrichetta Soccio \\ University “G. d’Annunzio”, Chieti, Italy
}

\begin{abstract}
George Meredith (1828-1909) is acknowledged as a creator of memorable female characters. Meredith’s heroines are radically different from the women generally encountered in Victorian fiction. Characteristically, Meredith constructs a type of female character who, in a social context hostile to any break with convention, refuses to conform to the stereotype of the weak, passive, and dependant woman. In accordance with J. S. Mill's observations in The Subjection of Women (1869), Meredith thought that the progress of society could be possible only through female emancipation and admittance of women into public practice. This paper discusses the themes of marital disintegration and "conscious adultery” that affirm the legitimacy of female pleasure against coercion. Thus, the paper will take into consideration the sonnet sequence Modern Love (1862) and one of Meredith’s most neglected novels, Lord Ormont and His Aminta (1894), whose heroines are unexpectedly depicted as non-conventional, strong, and proud. A close reading of the texts will reveal the narrative strategies and textual devices through which Meredith exploited a model of womanhood that, by subverting the current ideas on sex, marriage, and gender roles, is able to countermine male "egoism", the only obstacle to the genuine progress of Victorian society toward real democratization.
\end{abstract}

Keywords: George Meredith, Victorian women, love, sex, gender, subversion

\section{Introduction}

Towards the end of the 19th century, the representation of women in literature was progressively being transformed. In fiction and poetry, the traditional idea of women as passive, powerless, and dependant creatures gave way to a new view of femininity. Such a rethinking largely stemmed from the predictable changes produced by the numerous debates and discussions on social matters, gender roles, and the value of domesticity and family. It is well known that Victorian society was riven with conflicts and contradictions. The Victorians were constantly in search for social order and ethical unity; yet, as Marroni (2010) had aptly stated: "[T]he Victorians felt continually besieged by the specter of disharmony [...]” (p. 11). The image of an ordered society presided over by Queen Victoria as formidable matriarch coexisted often uneasily with an unremitting struggle against disorder. The Victorians, nonetheless, were conscious that they lived in an age of sharp contrasts involving almost every class of society. Like many other important topics, the role of women, at home and in society at large, was much debated as part of a more general discourse on domesticity and family ideology. In 
1865, John Ruskin sanctioned the separation between "public" and "private" spheres and, consequently, between male and female roles:

The man's power is active, progressive, defensive. He is eminently the doer, the creator, the discoverer, the defender [...] But the woman's power is for rule, not for battle,--and her intellect is not for invention or creation, but for sweet ordering, arrangement, decision. (Ruskin, 1932, p. 61)

As opposed to stereotyping the woman as the chaste angel of the house or, alternatively, the corrupted femme fatale, George Meredith (1828-1909) represented, in his work, an idea of femininity that diverged from that of the literature of his time. Almost unique in his treatment of such a topic, Meredith gave voice to unorthodox, strong-willed and affirmative female characters, thereby contributing significantly to undermine the ongoing belief that "women were simply not capable of dealing with life beyond domestic and motherly duties" (Gardiner, 2002, p. 16).

\section{Modern Love and the "Unholy Battle" of the Sexes}

Despite the many prejudices against his works raised by his contemporaries who thought him too audacious in treating topics which were considered improper and even immoral (Griest, 1970), and too difficult in style, George Meredith (1828-1909) has been always regarded as "the Grand Old Man of Box Hill" and the “champion of women”, as Virginia Woolf and Alice Woods, in 1932 and 1937 respectively, called him. Meredith started his career as a poet with the publication of a collection entitled Poems in 1851. At the time, he was only 23 and most of the poems there included were written when he was very young. In that first collection, several poems dealt with the beautiful English landscape, but the most memorable of all remains "Love in the Valley" (1851), a romantic hymn to love and nature in which the husband's desire for his wife is "identified with his duty to marry" (McGhee, 1980, p. 168). What emerges in the eight-line stanzas of the poem is a process of de-idealization of love that drives passion and sensual innocence into marriage, and then results in a joyful and rapturous vision of natural life.

Meredith's idea of love, however, changes in Modern Love (1862), a sequence of 50 sonnets published 10 years later, in 1862. It would be tempting to see this work as the mere recording of Meredith's failure of his marriage with Mary Ellen Nicolls, daughter of Thomas Love Peacock, and widow of a lieutenant in the Royal Navy. By the time Modern Love was completed, Mary Ellen had already eloped with Meredith's best friend, the pre-Raphaelite painter Henry Wallis, and had died, after a long tormented and sometimes even violent relationship with her husband (Stevenson, 1954, pp. 57-59, 95-96), of a form of Bright disease ${ }^{1}$. That the poem's first germ is contained in Meredith's autobiographical experience is largely acknowledged, but it must be remembered that Modern Love was conceived as part of a more extensive project of renovation and exploitation of traditional poetic forms that involved an idea of poetry as "narrative in verse”. Meredith (1912) himself, in a letter to Rev. Augustus Jessopp, dated November 13, 1861, wrote:

I rarely write save from the suggestion of something actually observed. I mean, that I rarely write verse. [...] I desire to strike the poetic spark out of absolute human clay. And in doing so I have the fancy that I do solid work-better than a carol in mid air. (p. 45)

\footnotetext{
${ }^{1}$ A form of nephritis, as explained by Stevenson, 1954, p. 96.
} 
The observation of the real world and the recording of human experience are transmuted into a spiritual quest made up of fragments that the poet calls "sonnets" in order to narrate the story of a "modern love". Here Meredith's impulse toward experimentation is clear in his original treatment of one of the most conventional poetic forms. Apart from being 16 lines long (four ABBA rhyming quatrains), Meredith's sonnet is intended as lyric and narrative at the same time. Moreover, instead of celebrating the joys of love in the fashion of the Renaissance sonnet sequences, Modern Love accounts for the crisis of romantic love in Victorian times. Even though his own failing marriage lies behind the whole poem, Meredith, however, goes further in his reflection on the meaning of marriage and the transformation of the complex relationship between husband and wife in contemporary times.

In a thought-provoking article, Crowell (2010) has recently suggested that Meredith is using the sonetto caudato, a poetic form of the Renaissance, whose employment serves for satirical and comedic purposes. According to Crowell (2010): "Modern Love contains a comprehensive critique of both progressive and regressive elements of Victorian society, and this critique is augmented by the suggestion of political action contained within the caudato form" (p. 540). In other words, form reflects content: Critique to society is possible through a suitable poetic form and the sonetto caudato certainly appeared as the most effective for exploring “modern" times.

As Meredith himself said, lamenting the unenthusiastic reception of the poem by critics: “'Modern Love' is a dissection of the sentimental passion of these days, [that] could only be apprehended by the few who would read it many times” (as cited in Meredith, 1912, p. 156). By suggesting the elitist nature of his readership, he reveals the guiding principle that animates his writing: That is to say, his intention to grasp reality through close investigation of the dramatically fast transformation in society that, in his view, entailed a radical change in gender relations. "Love"-always written with a capital letter in the poem-represents an ideal that is progressively deteriorating: From the courtly vision of the lovers who live in a condition of perpetual desire, love becomes a "sentimental passion" that requires to be "dissected" (deception, frustration, and finally, tragedy) and resembles more and more a game of subtle moves played between men and women. Indeed, the first title for the poem was Love-Match, a lexical pair that evokes a contest between the sexes apparently conducted on equal terms. Both protagonists have important roles to play in the game; both have extra-conjugal affairs; both deceive the other and are self-deceived. Not surprisingly, some years later in his Essay on the Idea of Comedy (1877), Meredith (1913) defined Comedy — for him the highest form of literary expression—as "an exhibition of [women's] battle with men and that of men with them: and as the two, however divergent, both look on one object, namely Life, the gradual similarity of their impressions must bring them to some resemblance” (pp. 29-30). As has been recognized by contemporary and later critics alike, Meredith's heroines strive for spiritual and emotional independence as well as for an affirmation of their own identity as women. This is very likely the most "Meredithian" aspect of his writing: He constructs a gallery of women, whether of humble or noble origins, who struggle to impose their intellectual abilities and change the idea of woman as a passive, inanimate creature, subjected to male authority, which pervades respectable Victorian society. Paradoxically, the unconventionality of his theme—romantic idealism dissolving "into a mere sentimental passion" (Golden, 1973, p. 268)—needs an orthodox structure - the sonnet—which is nevertheless experimented upon in order to shock the audience. 


\section{Women: Demons or Angels?}

It would be interesting now to look at those sonnets of Modern Love in which the female protagonist, the unnamed wife, and the husband's mistress subvert the Victorian idea(l) of woman. Contrary to contemporary stereotypes, it is the husband's point of view that dominates the narration of his pain and anger at his wife's adultery. However, although the speaker shows very little insight in the wife's emotional state, there is neither overt condemnation of the woman nor piety for the man. Indeed, Meredith deliberately charges both protagonists with contributing to the failure of their marriage. Surprisingly enough, as Jones (1999) had recognized: “The effect [of his wife's adultery] on Meredith was to deepen the sympathy for women that resounds as a leitmotiv through all his novels” (p. 94).

The sonnet sequence opens with the couple in bed: She is weeping, he is becoming aware that the reason for her coldness is her passion for someone else. She "lay/stone-still” (Meredith, 1995, I, p. 2) ${ }^{2}$, thinking of another man, and the following morning, she appears in all her guilty beauty before her husband as:

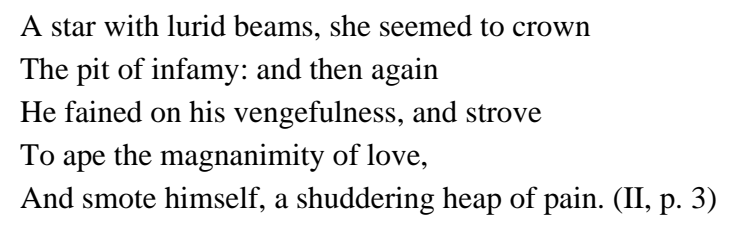

A mixture of love and hatred, desire and revulsion at the sight of her agitates her husband's mind, although he cannot help recognizing that his wife is not the only one responsible for the dissolution of their marriage. She is also seductive and determined, and for this reason she is seen as a "bitter barren woman” (VI, p. 7), a “devilish malignant witch" (IX, p. 10), a "banished angel” (XXIII, p. 24) whose “cruel lovely pallor which surrounds her footsteps", and "that nun-like look" (XXIV, p. 25), still exert a strong power on him, a power involving senses, heart, and mind. Unlike the devoted, remissive wife of Victorian imaginary, she literally dominates the relationship: (1) It is the wife who has the faculty to choose between husband and lover (XXV, p. 26); (2) It is the wife who holds the reins of the story; and (3) It is the wife who controls the husband's states of mind. Moreover, her unconventionality lies in the fact that, whatever sin she commits against her husband, society, and religion, we readers cannot_and Meredith himself with us_-but take her side (Holmes, 2010, p. 533). Obviously, by opting for adultery and the violation of Victorian sexual mores, the wife affirms herself by appropriating men's social behavior for her own purposes, and for all that even the speaker, notwithstanding his feelings of extreme jealousy, makes us sympathize with her.

Also the mistress, who is described as a woman who "has wit" (XXXI, p. 32) and the "rarest gift to beauty, Common Sense” (XXXII, p. 33), is unconventional in her accepting a Platonic love that significantly diverge from the expected behavior. Instead of being the dark seductress, the tempting demon of traditional imagery, the "lady" is a "fair angel" whose wit and wisdom paradoxically make her an ideal of femininity. Here we have a startling subversion of the two stereotypes (as cited in Golden, 1973, pp. 274-275) that testifies to the complexity and the distortion of the husband's vision of love. In dramatizing the relationship/conflict between husband and wife, man and mistress, Meredith offers a vision of the woman that uniquely departs from the Victorian ideal.

${ }^{2}$ All quotations are from this edition. Hereafter sonnet number and page reference will appear in the text. 
Such a dramatization, however, results in exposing and resisting an epistemic framework that, in Meredith's view, is growing obsolete and unsuitable to "modern times".

\section{Subversion of the Victorian Idea(l) of Femininity}

This need for an urgent epistemic change is even more evident in Meredith's novels. The author of this paper would like to focus her attention on one of Meredith's last novels, written in 1894, Lord Ormont and His Aminta, that can be seen, as Roberts (1997) has aptly argued, "as the culmination of a sequence of Meredithian approaches to the theme of female liberation from patriarchal marriage” (p. 240). Aminta Farrell, the novel's heroine, comes after the experience of other heroines such as Clara Middleton in The Egoist (1879) and Diana Warwick in Diana of the Crossways (1884), whose courageous attempts at extricating themselves from betrothal and marriage have paved the way for a more daring challenge to the Victorian institutions for the legitimation of women's free will.

At its publication in 1894, Lord Ormont and His Aminta was coldly if not negatively received by the critics who considered it as "weak”, “empty”, “unnatural and incredible”, even "unspeakable” as James (1980, pp. 485-486) called it in a letter to Edmund Gosse. Not only does the story pose a moral problem—a young woman abandons her old husband to start a new (adulterous yet in a sense morally legitimized) life with a younger suitor; it also raises a host of questions about female education, free will, and resistance to social stereotypes.

As usual in Meredith's novels, Lord Ormont and His Aminta begins with a chapter in which facts preceding the story are told in order to give the reader proper information about past events involving the main characters. In Chapter I, we find a schoolgirl, Aminta (Browny) Farrell, the novel's heroine, and a schoolboy, Matthew (Matey) Weyburn, the "modern hero". Since their first meeting, Aminta appears in all her eccentricity: She is beautiful but "[...] she was dark enough to get herself named Browny. In the absence of a fair girl of equal height to set beside her, Browny shone" (Meredith, 1916, p. 3). Although the nickname given by the boys suggests that her beauty does not correspond to traditional standards, it is recognized that she is a shining beauty. The oxymoron "Browny shone” signals a subversion of conventional images of female beauty:

Some of the boys regretted her not being fair. But, as they felt, and sought to explain, in the manner of the wag of a tail, with elbows and eyebrows to one another's understanding, fair girls could never have let fly such look; fair girls are softer, woollier, and when they mean to look serious, overdo it by craping solemn; or they pinafore a jigging eagerness, or hoist propriety on a chubby flaxen grin; or else they dart an eye, or they mince and prim and pout, and are sigh-away and dying-ducky, given to girls' tricks. Browny, after all, was the girl for Matey. (Meredith, 1916, p. 4)

In Chapter II, the story starts by presenting a married couple, Lord Ormont, a middle-aged man, the hero of the British Navy, and his wife, the young Aminta Farrell, married in Spain and never officially presented in society. She is now the wife of a cavalry general whom she, as a schoolgirl, worshipped but, just like her unconventional appearance, she lives an unconventional marriage that will be rejected in order to gain independence as a "new" woman with a "new" man.

\section{The Sea Imagery as Narrative Strategy}

As far as we are concerned here, it must be recognized that Aminta is the most audacious of Meredith's heroine in terms of sexual behavior. Portraying her as belonging to nature and free from social concerns is a part 
of the writer's evolutionary perspective according to which "it is the female who selects her mate, or at the very least has the option of rejecting those who do not please her” (Smith, 1995, p. 61). Aminta is very often described in connection with the sea: She swims; she loves the sea deeply; she has a sea-mind (Meredith, 1916, pp. 254, 279, 320). Time and again, the sea imagery is used to refer to Aminta and her relationship with Matthew and the sea flowing is also reflected in the language and style. In the climactic scene of the novel contained in Chapter XXVII, significantly titled "A Marin Duet", the two protagonists are transformed into sea creatures—water-flowers, sea-birds—to mean a supreme spiritual freedom (Soccio, 2001, pp. 116-121). After meeting in the sea, the two swim together in a sort of divine union celebrated by "old Triton":

For nothing further would astonish her, as he rightly understood her; but he said: "You're prepared for the rites? Old Triton is ready."

"Float, and tell me."

They spun about to lie on their backs. Her right hand, at piano-work of the octave-shake, was touched and taken, and she did not pull it away. Her eyelids fell.

"Old Triton waits."

"Why?"

"We're going to him."

"Yes?"

"Customs of the sea."

"Tell me.”

"He joins hands. We say, 'Browny-Matey,' and it’s done.”

She splashed, crying "Swim,” and after two strokes, "You want to beat me, Matey Weyburn."

"How?"

"Not fair!"

"Say what."

“Take my breath. But, yes! we'll be happy in our own way. We're sea-birds. We've said adieu to land. Not to one another. We shall be friends?”

"Always."

"This is going to last?"

"Ever so long."

They had a spell of steady swimming, companionship to inspirit it.

[...]

They swam silently, high, low, creatures of the smooth green roller. He heard the water-song of her swimming. She, though breathing equably at the nostrils, lay deep. The water shocked at her chin, and curled round the under lip. He had a faint anxiety; and, not so sensible of a weight in the sight of land as she was, he chattered, by snatches, rallied her, encouraged her to continue sportive for this once, letting her feel it was but a once and had its respected limit with him. So it was not out of the world. (Meredith, 1916, pp. 321-322) ${ }^{3}$

The scene is imbued with symbolic meaning. The almost obsessive recurrence of words, whether belonging or referring to the sea, and the mythological allusion to sea-gods evoke a fantastic atmosphere that leaves no doubt about the narrator's purpose of creating an unique dimension for the couple. By using the sea as an "organic metaphor" (Beer, 1970, p. 103) that stands for birth and life, purity and innocence, and fertility and sexuality, Meredith (1916) suggested that Matthew and Aminta are made of the same "fluid" substance and thus made for one another. Fluidity means change and adaptability, that same change which late nineteenth-century society invoked, and that same adaptability which was necessary to the survival of the fittest.

\footnotetext{
${ }^{3}$ Italics added.
} 
The "marine duet" scene is, moreover, extremely subversive in exposing the sexual side of the protagonists, whose marriage of "true minds" is celebrated in the sea. The description of the couple in total union with nature, and very far from the constraints of civil society, establishes a new paradigm extolling what the Victorian social conventions disapproved. As can be easily observed, in the following scene Matthew and Aminta recognize one another as the boy and girl of many years back-Matey and Browny—only to affirm that they are grown up and fully aware of their choices:

Was [Matey] unaware that they were boy and girl again? — she washed pure of the intervening years, new born, by blessing of the sea; worthy of him here! - that is, a swimmer worthy of him, his comrade in salt water.

"You're satisfied I swim well?" she said.

"It would go hard with me if we raced a long race."

"I really was out for France."

"I was ordered to keep you for England.” She gave him Browny’s eyes.

"We’ve turned our backs on Triton."

"The ceremony was performed."

"When?”

"The minute I spoke of it and you splashed."

"Matey! Matey Weyburn!”

"Browny Farrell!”

“Oh, Matey! she’s gone!”

"She’s here."

“Try to beguile me, then, that our holiday’s not over. You won’t forget this hour?”

"No time of mine on earth will live so brightly for me."

"I have never had one like it. I could go under and be happy; go to old Triton, and wait for you; teach him to speak your proper Christian name. He hasn’t heard it yet,-_heard 'Matey,'—never yet has been taught 'Matthew.'”

“Aminta!” (Meredith, 1916, pp. 323-324)

At a symbolic level, the ceremony of the ideal wedding has been performed before "old Triton"-the mythological messenger of the sea, who stands for the divinity officiating the union of the two and justifies, on a moral level, what would never be allowed on a social level. Moreover, the sea imagery implies a sort of sexual experience that conveys the complete union of man and woman in body and soul. By emphasizing the pagan-like sentiment for the natural elements, Meredith offers his version of modernity for which the female ethical point of view prevails. It is not a surprise, then, that the novel's hero is called "the brother of women” (Meredith, 1916, p. 285), a "new man" who is able to "read" women and treat them on an equal level.

Finally, the reference to Matthew's penchant for teaching in the last few lines of the above quotation alludes to the constant interest in pedagogy that runs throughout the novel. In fact, one of the most crucial issues discussed in Meredith's corpus in connection with his study of women and gender roles is education. In Lord Ormont and His Aminta, Meredith's critique of marriage is also developed through a sense of the urgency to change the education system in favor of a higher number of women to be allowed in schools. Teaching is the main aspiration that the protagonists of this novel hold in common: they will set up a school in Switzerland whose project is to bring "all nationalities [...] without distinction of race and religion and station" (Meredith, 1916, p. 155) together, with "boys and girls in one group, never separated, declaring it the only way for them to learn to know and to respect one another" (Meredith, 1916, p. 31). This is Meredith’s most progressive view of

\footnotetext{
${ }^{4}$ Italics added.
} 
society: only by improving the education system and allowing both young men and young women to take part in it, can society develop toward real progress. At the end of the novel, Aminta's role as co-educator and her choice of "a partnership based on equality and respect” (Jones, 1999, p. 169) rather than a marriage with a "respectable” member of the English upper class summarize Meredith's idea of womanhood which violates the Victorian sense of social order. In championing the women's cause for social rights, Meredith contributes, perhaps more than any other male writer in the fin de siècle, to change the 19th-century image of woman and sets out on new paths for future developments.

\section{Conclusions}

In conclusion, both in poetry (Modern Love) and in fiction (Lord Ormont and His Aminta), Meredith offers two examples of his strategies to represent a new model of women and to forge an alternative notion of femininity. As can be seen in the works discussed above, Meredith is interested in showing what women think and feel, and thus, he constructs his stories by subverting traditional stereotypes and common ideas of womanhood and relationship between the sexes. By developing "female plots", that is to say, fictional patterns which make the woman's mind and her intellectual abilities emerge as driving forces in the progress of society, Meredith undoubtedly prefigures certain the 20th-century key concerns about female conditions and female struggle for self-determination.

\section{References}

Beer, G. (1970). Meredith: A change of masks: A study of the novels. London: The Athlone Press.

Crowell, K. (2010, Winter). Modern love and the sonetto caudato: Comedic intervention through the satiric sonnet form. Victorian Poetry, 48(4), 539-557.

Gardiner, J. (2002). The Victorians: An age in retrospect. Hambledon and London: Hambledon Continuum.

Golden, A. (1973, Summer). “The game of sentiment”: Tradition and innovation in Meredith’s modern love. ELH, 40(2), $264-284$.

Griest, G. L. (1970). Mudie’s circulating library and the Victorian novel. Bloomington: Indiana University Press.

Holmes, J. (2010, Winter). Darwinism, feminism, and the sonnet sequence: Meredith's modern love. Victorian Poetry, 48(4), 523-538.

James, H. (1980). Letters. L. Endel (Ed.). London and Basingstoke: Macmillan.

Jones, M. (1999). The amazing Victorian: A life of George Meredith. London: Constable.

Marroni, F. (2010). Victorian disharmonies: A reconsideration of nineteenth-century English fiction. Cranbury: Associated University Press.

McGhee, R. D. (1980). Marriage, duty and desire. Lawrence: Regents Press of Kansas.

Meredith, G. (1913). An essay on comedy and the uses of comic spirit. London: Constable.

Meredith, G. (1916). Lord Ormont and his Aminta. London: Constable.

Meredith, G. (1995). Modern love. G. Beer (Ed.). London: Penguin-Syrens.

Meredith, W. M. (Ed.). (1912). Letters of George Meredith. New York. Scribner's Son.

Roberts, N. (1997). Meredith and the novel. Basingstoke and London: Macmillan.

Ruskin, J. (1932). Sesame and lilies. G. E. Hollingworth (Ed.). London: W. B. Clive.

Smith, J. (1995, June). “The cock of lordly plume”: Sexual selection and the egoist. Nineteenth-Century Literature, 50(1), 51-77.

Soccio, A. E. (2001). George Meredith: Romanzo e sperimentazione. Pescara: Edizioni Campus.

Stevenson, L. (1954). The ordeal of George Meredith. London: Peter Owen.

Woods, A. (1937). George Meredith as a champion of women and of progressive education. Oxford: Blackwell.

Woolf, V. (1932). The common reader (2nd Series). London: The Hogarth Press. 